\title{
Editorial: A time for reflection
}

\section{GLOBAL CHANGE}

On a global scale, the last decade was a time of immense change. Perhaps this is why the mood across the world was to celebrate the end of the Millennium in such spectacular style. From the breaking down of the communist regimes in Eastern Europe, to the rise of the Internet and mobile phones as major communication tools used in both business circles and socially, old paradigms have been challenged. One consequence of these changes has been the facilitation of global business and the much freer flows of capital internationally.

These changes have provided the environment for corporate expansion, and consequently, there has been a spate of corporate take-overs affecting all sectors of business, not least the leisure sector. The big have got bigger, to such an extent that, measured in terms of output size, over half the world's top economies are corporations, not nation states. ${ }^{1}$ Hertz and other commentators ${ }^{2}$ argue that this shift of economic power from elected bodies to selfdetermining corporate entities is affecting all aspects of life - from social attitudes to the process of winning development approvals.

The rise of the corporation and the decline in the ability of governments to stimulate interest in the democratic process ${ }^{3}$ was amply illustrated in the recent UK General Election in which the turnout was the lowest for almost a century. If the collective democratic process falls into disuse, then social attitudes move towards a greater expression of self-determinism and individuality.

But what has all this to do with the state of the leisure property markets, as revealed through the current edition of the Journal? On the face of it, very little. However, a closer examination reveals that there is a thread of disquiet within the markets which represents a shift from the confidence that was expressed only a few months ago. This thread is also demonstrated by the recent news that developers THI have run into financial difficulties. From a situation in which leisure was seen by developers and investors alike as the rising star, a new mood of realism and caution has taken hold.

\section{A THEME OF CAUTION}

In this issue's regular feature, the analysis of economic trends by Cox will make uncomfortable reading for some. Pointing to the essentially diverse nature of leisure, Cox makes the point that for successful future developments it may not be sufficient merely to analyse demographics and the level of supply. Instead, she argues, there will be the need to recognise that economic change has led to a breaking down of established social norms. Building on the views of other commentators she maintains that it is now less a question 
of providing a leisure venue, but more a leisure experience in which an ongoing relationships between the venue and the visitor is established and cultivated. This philosophy is not new; it has been set out previously by Pine and Gilmore ${ }^{4}$ within the US business culture and, arguably, is inherent within a 'traditional' service ethos that was the hallmark of the retail offer. What is newer is its incorporation specifically within the leisure property design process, a point made eloquently to a Leisure Property Forum meeting by Burrows when he detailed the concept behind the Heron City Brand. ${ }^{5}$

So, the message coming from Cox is unequivocal. The simple 'one size fits all' solution, as epitomised by the first generation of leisure parks, is no longer a guarantee of success, even in a time of continued economic prosperity for leisure as measures in aggregated consumer spending figures. This point is amply illustrated by the findings of Sayce, Smith and Walker in respect of multiplex cinemas. The rapid growth in rental values experienced in the UK over the early to mid 1990s, has not been sustained as supply levels have grown in excess of sustainable demand. Investors and occupiers alike, now locked into inflexible standard commercial lease arrangements, may have to renegotiate terms if the long-term viability of the units is to be assured.

\section{FROM PROVISION TO MANAGEMENT}

The implication of this is that a loss of flexibility resulting from moves to emulate other commercial leasing agreements may be at odds with the essentially volatile and shifting patterns of leisure expression, as detailed in Walker's historical perspective. It is not that there is anything intrinsically new about leisure property; it is the form that it takes and the expectations of those who develop and own it that have changed. So, the emphasis has to be on recognition of the requirement to manage the asset proactively. It is in relation to this that the Journal contains Sesnan's interesting case study of innovative leisure management in the shape of Greenwich Leisure Limited who have developed an award-winning ${ }^{6}$ model for private-public cooperation that has helped secure the continued provision of affordable leisure facilities in an area of intense social need and stretched public financial resources.

Lillie also develops the theme of caution in the UK leisure market in relation to bars and restaurants. His findings, taken from an analysis of market transactions, are that rental and capital growth within the out-of-town and edge-of-town leisure parks are not being realised and that this has led to changing investor and corporate-occupier sentiment. And here there is a connection back to the global market. If large corporate players such as Whitbread make fundamental strategy changes, the effects are only too real at local, national and international levels. This places pressure on all local and national governments to respond and provide the context within which large corporate entities can succeed. 


\section{MEETING THE NEEDS OF THE CORPORATE}

Within the UK, the need to respond to the changing social patterns and to facilitate corporate players is recognised. The difficulty is how? Two recent publications are very important to all those concerned with leisure property in the UK. The first is the proposals for licensing reform, the second is concerned with planning for leisure and tourism. The UK licensing laws, which date back to the 1960s, have long been recognised as being in need of reform due to their complexity and the difficulties they present to the police, in terms of enforcement; to operators, in terms of economic efficacy; and the local populace, in terms of social environment. Poppleston's analysis of the current proposals provides an insight into the arguments that will arise when the Bill introduced for reform, and the conflicting views of all stakeholder groups, are brought into focus. Will the economic arguments hold sway over the views of some local authorities that restriction of licences is necessary in the interests of their communities?

The other area of reform that has been highlighted relates to planning issues. This has recently been the subject of a major government review which recommends over 30 changes to legislation and/or planning policy. Although the authors do not propose any radical changes to the underlying system, the proposals if implemented would have major implications for both developers and operators. While this report is too recent to be included within the scope of this edition of the Journal, the results of the consultation on the report and associated changes will doubtless form the basis for future contributions.

So, the leisure property market appears to be entering a period during which the ability to think laterally and to accommodate all stakeholders' desires will sign success. Leisure property is responsible for providing society with the outlet it craves; it must continue to challenge established values, however uncomfortable the recipients find it. Leisure property and providers must lead the way - they have a large and willing following.

Sarah Sayce June 2001

\section{References}

1. Hertz, N. (2001) The Silent Takeover, Heinemann, London

2. See for example Handy C (1997) The Hungry Spirit, Hutchinson, London, and Mombiot, G. (2000) Captive State: the corporate take-over of Britain, Macmillian, London

3. See reference 1 above, at p.107.

4. Pine, B. J. and Gilmore, J. H. (1999) The Experience Economy, Harvard Business School Press, Boston Mass

5. Burrows, J. in a presentation entitled Heron City: building the brand to the LPF meeting January 2001.

6. Greenwich Leisure was the winner of the LPF 2000 Award for Best Leisure Operator. 